УДК 04.353

Т. Ю. КАюева

Інститут проблем реєстрації інформації НАН України

вул. М. Шпака, 2, 03113 Київ, Україна

\title{
Аналіз сучасного стану технологій зниження спеклових шумів у переносних мазерних проекторах
}

\begin{abstract}
Розглянуто типи лазерних проекційних систем та охарактеризовано основні технології відтворення зображення. Проведено аналіз методів зниження спеклових шумів у лазерних проекторах. На основі аналізу способів декорелячії лазерних променів запропоновано класифікачію методів зменшення когерентних шумів, визначено основні переваги методів і їхні недоліки. Показано, щцо активні методи зниження спеклових шумів є найбільш ефективними.
\end{abstract}

Ключові слова: лазерний проектор, сканування, спекли, дифракиійні елементи.

\section{Вступ}

В останні роки проекційні технології продовжували бурхливо розвиватись $\mathrm{i}$ сьогодні використовуються в різних галузях діяльності людини. Поява нових мініатюрних джерел світла 3 великою яскравістю, а також активне застосування проекційної техніки в мобільних пристроях, вимагає пошуку нових рішень при створенні проекторів. Нові досягнення у технологіях діодів і пристроях MEMSсканування сприяють розвитку лазерних проекційних систем. Лазерні діоди мають малі розміри та створюють пучки світла великої потужності з малим діаметром. Це дозволяє створити на їхній основі оптичні системи проекторів з малими габаритами та вагою. Крім того, сканування лазерним променем також забезпечує високу роздільну здатність і значно більшу насиченість кольору.

Проте використання лазерного освітлення в компактних проекторах має не лише переваги, але і значну проблему. В лазерних проекторах отримане зображення промодульовано когерентними шумами - спеклами, які виникають унаслідок інтерференції відбитого від екрана когерентного світла та помітно погіршують якість отримуваного зображення. Тому отримання якісного зображення вимагає створення ефективної системи зменшення спеклових шумів.

\section{Типові архітектури проекційних систем}

Існують два різні підходи до відтворення зображення лазерними проекторами. Один із них базується на повному одночасному відтворені зображення оптич- 
ним модулятором (повноформатний проектор), інший - на відтворені оптичним модулятором частини зображення 3 наступним скануванням лазерного променя по екрану (технологія сканування).

Розглянемо більш детально вищезазначені технології.

У типовій системі повноформатного проектора використовується невеликий 2D-оптичний модулятор, який освітлюється однорідним пучком світла та формує зображення. Потім мікрозображення, що створене модулятором, збільшується та проектується на екран.

Функції оптичного модулятора у деяких типах проекторів виконує LCD (Liquid Crystal Display) - матриця, де зображення створюється пучком світла, що пройшов через LCD. Для темного пікселя на зображенні відповідний піксель у LCD перемикається в стан поглинання, для яскравого - піксель LCD перемикається в стан пропускання.

Ще одна технологія, яка базується на відбиванні світлового пучка, — LCoS («рідкі кристали на кремнії») - технологія, що використовує активну кремнієву підкладку (backplane). Схема управління пікселем у даній технології знаходиться під світловідбиваючими електродами пікселів і не створює перешкод для відбитого світла. LCOS-модулятор однаково ефективно працює з усіма джерелами світла, але має складну технологію виготовлення. Крім цього, через складність оптичної системи модуль 3 LCOS-мікродісплеєм має значно більші габарити.

Інша реалізація 2D-оптичного модулятора - це 2D-матриця, що складається 3 великої кількості електронно-керованих мікродзеркал, розмір яких приблизно 1 мкм. Такі матриці позначаються абревіатурою DMD (Digital Micromirror Device - цифровий мікродзеркальний прилад), а технологія, на якій засновано їхній принцип діï, - DLP (Digital Light Processing - цифрова обробка світла) [1]. Ця технологія розроблена компанією Tехаs Instruments.

На рис. 1 показано принцип роботи DMD-матриці. Кожне 3 мікродзеркал має можливість відображати падаюче на нього світло або в об'єктив, або в оптичний абсорбер. Яскравість пікселя визначається часом, протягом якого дане дзеркало відбиває світло в об'єктив, а час, у свою чергу, визначається тривалістю електричних імпульсів, які прикладені до дзеркала.

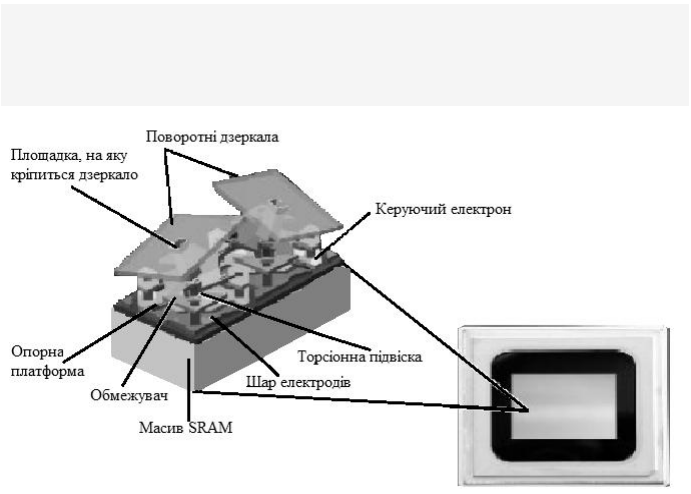

a)

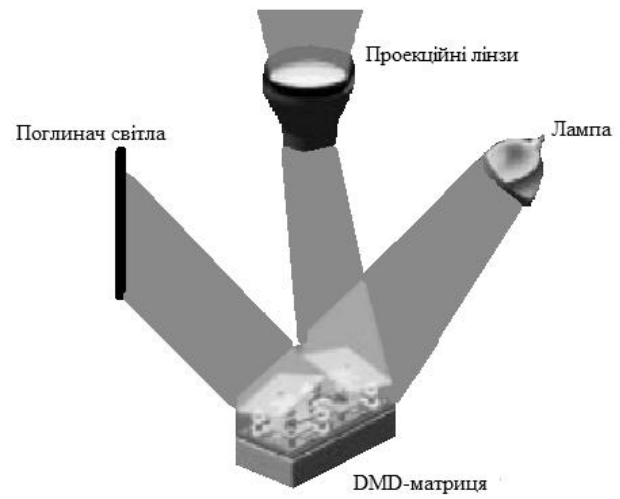

б)

Рис. 1. DMD-матриця [1]: а) схема двох дзеркальних пікселів поряд 3 типовим модулем світла $\mathrm{DMD}$; б) принцип роботи: один піксель відображає вхідне світло через проекційну лінзу до екрана, інший — відбиває світло від об'єктива 
Кожен дзеркальний піксель залежно від частоти зміни свого стану: 0-1, «закрито-відкрито», понад 10000 разів на секунду, здатний генерувати 1024 відтінки в діапазоні від білого до чорного. А у зв'язку з тим, що розмір 16 пікселів у такому модуляторі складає близько 10-20 мкм, з ним можна отримати високу роздільну здатність, а отже значно більший формат зображення на екрані.

Серед проекційних систем із застосуванням сканування зазвичай розрізняють лінійну та растрову.

Існує тип проекторів, у яких 2D-зображення на екрані створюється за допомогою смужки світла шириною в один піксель і висотою, рівною висоті екрана, 3 розподілом інтенсивності по висоті відповідно до проектованого зображення. При роботі проектора стовпчик світла із зображенням сканується вздовж екрана. При скануванні вздовж екрана модуляція в стовпчику змінюється відповідно до проектованого зображення, і таким чином створює на екрані 2D-зображення. Перші 1Dскануючі лазерні проектори Grating Light Valves (GLV) були розроблені компанією Silicon Light Machine [2]. GLV — це одномірна (лінійна) дифракційна гратка, яка являє собою керований електромеханічний модулятор, елементи якого можуть змінювати висоту за допомогою переміщення металевих стрічок шляхом прикладення напруги. Кожен піксель зображення $є$ невеликою дифракційною граткою, висота рельєфу якого може змінюватися незалежно від інших частин модулятора. Загальний вигляд такого модулятора зображено на рис. 2,a. Він складається з рухомих і нерухомих стрічок, що чергуються між собою, розташовані впритул одна до одної і мають однакову структуру. Стрічки виготовлено з діелектричного матеріалу з нанесеним на верхню поверхню металевим шаром (для відбивання світла). Парна група стрічок утворює один піксель зображення. Рухомі стрічки можуть рухаються вгору та вниз відносно нерухомих стрічок над нижньою поверхнею (дном) модулятора і таким чином створюючи дифракційну гратку. При падінні на оптичний модулятор колімованого пучка когерентного світла, внаслідок дифракції, відбите світло розділяється за різними дифракційними порядками, інтенсивність яких можна змінювати від нуля до максимуму залежно від положень рухомих мікродзеркал. Це справедливо для кожного пікселя зображення. Причому інтенсивність 0 дифракційного порядку змінюються в протифазі до вищих дифракційних порядків. Для створення зображення вибирають певний дифракційний порядок, як правило це або 0, або 1, або 1, або 1 i -1 дифракційні порядки, оскільки вони дають найбільшу інтенсивність світла в максимумі, а отже i дають найбільшу оптичну ефективність. Для цього у фокальній площині об'єктива розміщують діафрагму (у фокальній площині всі дифракційні порядки є просторово розділеними), яка пропускає тільки робочі дифракційні порядки. Висота рухомих дзеркал у кожному пікселі під час проектування зображення виставляється так, щоб інтенсивність робочого дифракційного порядку відповідала інтенсивності зображення. Роботу модулятора продемонстровано на рис. 2,б, де припускається, що робочими є 1-й дифракційні порядок. Якщо всі дзеркала виставлені на однакову висоту (рис. 2,8), маємо у відбитому світлі тільки 0-дифракційний порядок, який блокується діафрагмою у фокальній площині екрана. Тому в цьому випадку екран буде темний. У випадку коли дзеркала розміщені так, щоб давати напівхвильовий набіг фази між променями, відбитими від верхніх і нижніх дзеркал, ми маємо максимальну інтенсивність 1-го порядку та світлий екран. 


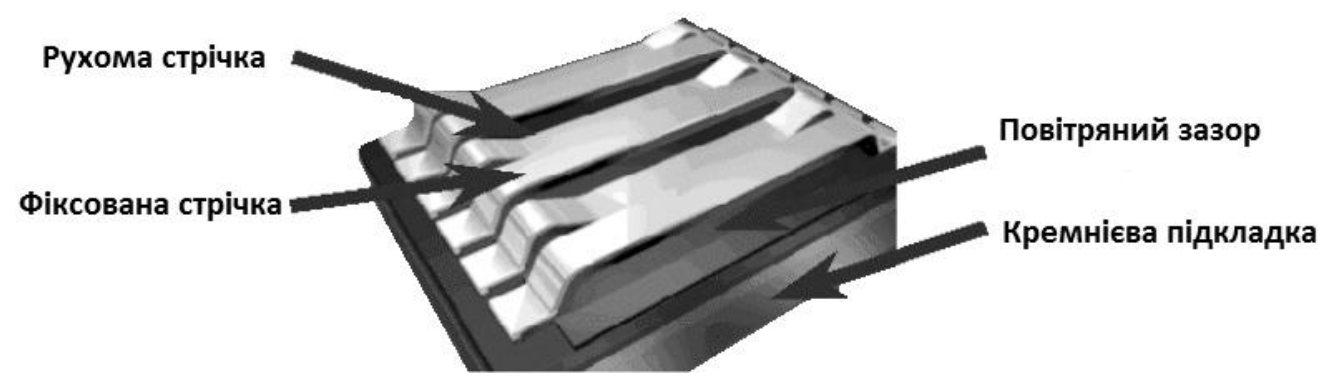

a)

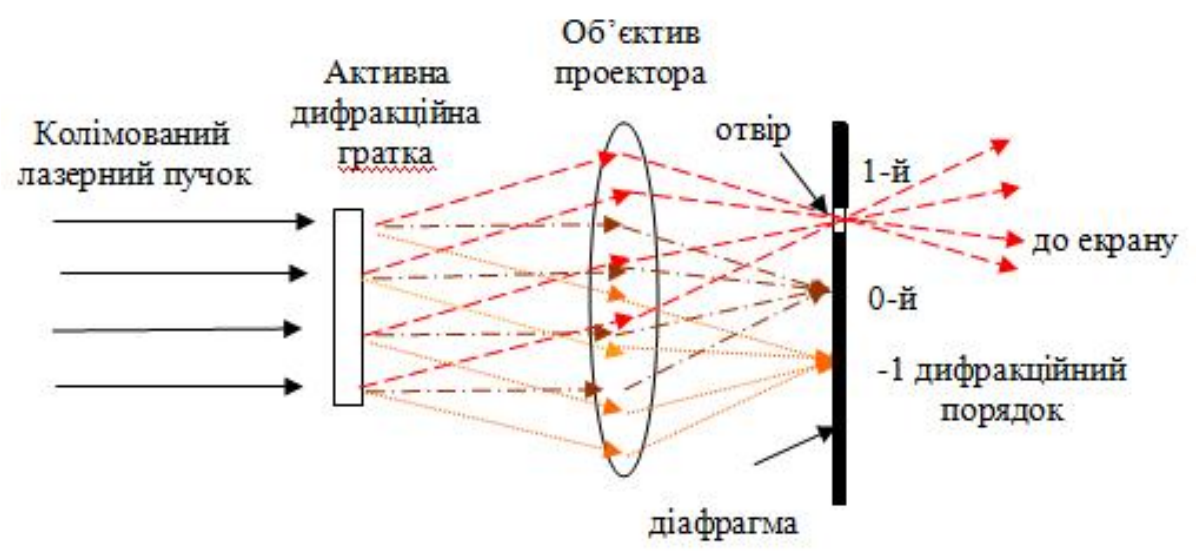

б)
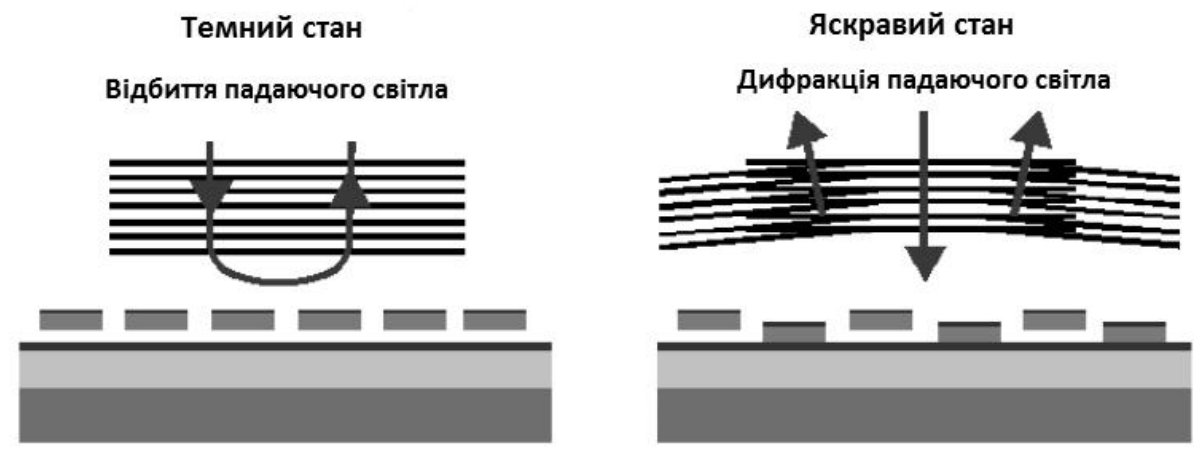

в)

Рис. 2 Оптичний модулятор GLV [2]:

а) загальна конструкція, яка складається з пар фіксованих і рухомих стрічок, що розташовані приблизно на чверть довжини хвилі над шаром діоксиду кремнію;

б) принцип роботи приладу, що оснований на використанні відбиття, дифракції і блокуванні всіх дифракційних порядків окрім 1-го дифракційного порядку;

в) принципова схема модуляції при створенні темного та світлого зображень

Перевагою GLV-технології є високий коефіцієнт модуляції, що забезпечено високою щільністю розташування елементів, а також висока роздільна здатність при низькій собівартості. 1D-скануючі лазерні проектори, які мають дещо інші 
1D-активні дифракційні гратки для створення зображення, були також розроблені компаніями Самсунг [3, 4] і Кодак [5].

Найбільш просту оптичну систему мають лазерні проектори, що сканують екран за допомогою тонкого променя, діаметр якого приблизно дорівнює розміру пікселя зображення. Інтенсивність променя повинна відповідати яскравості даного пікселя зображення. 2D-зображення створюють за допомогою сканування лазерного променя по екрану з відповідною модуляцією інтенсивності (яка досягається шляхом зміни струму живлення лазерних діодів), тому такі лазерні проектори називаються растровими або 1D (точковими) сканувальними проекторами.

Технологію сканування лазерного променя, яка реалізується на основі кремнієвого мікроелектромеханічного (МЕМС) пристрою, у центрі якого розташоване мікроскопічне скануюче дзеркало, розроблено компанією Microvision [6]. На рис. 3,a показано зображення цього надтонкого дзеркала, площа якого не перевищує одного квадратного міліметра, поряд з грифелем заточеного простого олівця.

Схематичний вигляд біаксіального МЕМС-дзеркала зображено на рис. 3,б. Двовимірний сканер 2D-MEMC коливається навколо вертикальної і горизонтальної осей для попіксельного відтворення зображення. Колімований промінь, що освітлює дзеркало внаслідок сканування у двох напрямках, створює на екрані повноцінне зображення.

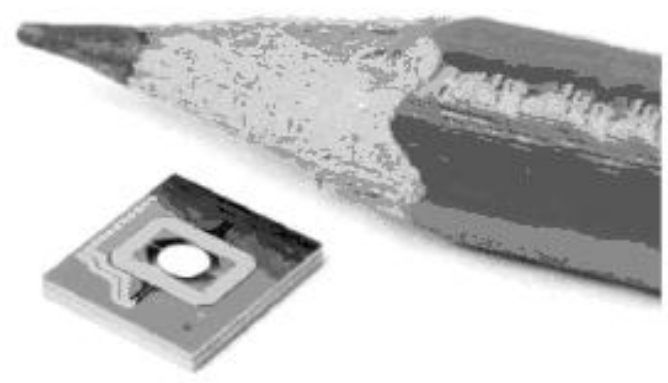

a)

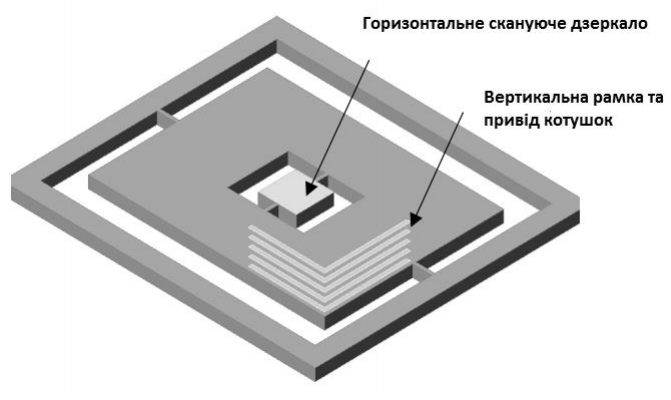

б)

Рис. 3. МЕМС-сканер Microvision [6]:

а) загальний вигляд мініатюрного дзеркала; б) схематичний вигляд

У растровому проекторі 0D-сканера відсутня необхідність застосовувати об'єктив, оскільки зображення на екрані формується за допомогою вузького колімованого променя, діаметр якого є приблизно рівним діаметру одного пікселя зображення. Це робить архітектури растрового сканування особливо прийнятними для пікопроекторів (проекторів, що мають найменші розміри в декілька десятків кубічних сантиметрів) та дозволяє отримувати зображення, що має безкінечну глибину фокуса, тобто отримувати проекцію на будь-якій відстані, а також на вигнутих поверхнях. Також до невід'ємних переваг представленої технології слід віднести низьку енерговитратність, оскільки все світло, що випромінюється, досягає екрана. Внаслідок модуляції інтенсивності лазерів зображення може мати великий контраст.

Для досягнення якісного зображення в растровому проекторі необхідно мати велику числову апертуру, тобто велике дзеркало, але воно не може швидко скану- 
вати екран. Тому простота конструкції призводить до великих проблем з якістю отримуваного зображення.

\section{Методи зменшення спекмів}

Спеклові шуми є мультиплікативними шумами (рівень шуму пропорційний рівню сигналу). Тому інтенсивність спеклових шумів визначається через контраст спеклів за формулою

$$
C=\sigma / \bar{I},
$$

де $\bar{I}$ - середня інтенсивність освітлення зображення рівномірно освітленого екрана; $\sigma$ - стандартне відхилення інтенсивності зображення (у випадку рівномірно освітленого екрана зміна в інтенсивності зображення повністю визначається спеклами). Значення контрасту спеклів може становити від 0 до 100 \%. Якщо значення контрасту спеклів знаходиться нижче $4 \%$, спекли фактично не будуть помітними для спостерігача [7-9]. Ефективність того чи іншого методу зменшення спеклів визначається коефіцієнтом зменшення спеклів $k$, який обчислюється за формулою

$$
k=C_{0} / C,
$$

де $C$ і $C_{0}$ - початковий рівень контрасту і контраст спеклів після застосування методу. На рис. 4 показано зображення в некогерентному світлі без спеклів (рис. 4,a) і в когерентному світлі 3 контрастом спеклів $45 \%$ (рис. 4,б). 3 порівняння двох зображень на рис. 4 можна зробити висновок, що спекли значно знижують якість і роздільну здатність зображення, і що зображення зі спеклами є неприємними для очей. Спекли є основним фактором, що стримують широке застосування лазерів у проекційних системах. Тому є очевидним необхідність вирішення проблеми зменшення спеклів для отримання якісного зображення при застосуванні лазерних проекторів.

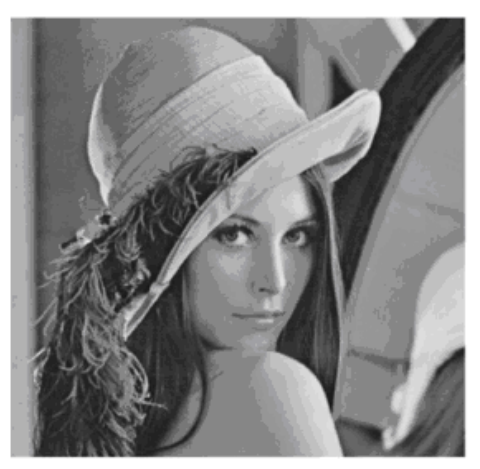

a)

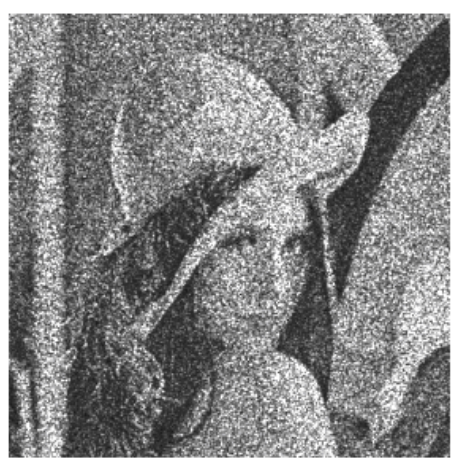

б)

Рис. 4 . Оригінальне зображення [9]:

а) зображення без спеклів; б) зображення зі спеклами

Для вирішення питання зменшення спеклів потрібно зменшити глибину модуляції зображення внаслідок інтерференції, цього можна досягти, тільки зменшуючи когерентність освітлення. Зменшення когерентності призводить до накла- 
дання в часовій послідовності один на одного спеклових полів протягом інтегрування оком світлової інтенсивності. Внаслідок усереднення шумів протягом цього часу їхня амплітуда зменшується. При накладені $N$ незалежних спеклових полів контраст спеклів зменшується в $\sqrt{N}$ разів. Не важко побачити, що для зменшення значення контрасту спеклів до рівня, яке прийнятне для людського ока, необхідно отримати приблизно 600-1000 декорельованих спеклових полів.

Можна зменшити часову, просторову чи поляризаційну когерентність лазерного освітлення. Будь-яка поляризація лазерного пучка може бути представлена через суперпозицію двох ортогональних поляризацій. Тому, зменшуючи поляризаційну когерентність, контраст спеклів можна зменшити не більше ніж у $\sqrt{2} \approx 1,4$ рази, отже цей метод має вельми обмежені можливості зменшення спеклових шумів.

Зменшення часової когерентності, тобто використання лазерного освітлення з відмінною від нуля шириною спектра, дозволяє отримати багато декорельованих спеклових полів. Декореляція двох когерентних лазерних пучків за рахунок різниці у спектрі залежить від шорсткості екрана, але, як правило, досягається не раніше ніж при різниці довжин світлових пучків не менше за 2 нанометри. Цей метод дозволяє значно зменшити контраст спеклів приблизно до $10 \%$ при ширині спектра в 100 нм. Проте досягти такої ширини спектра для лазерного освітлення $\epsilon$ практично нереальною задачею, але все одно це значення контрасту спеклів $є$ недостатнім для отримання якісного зображення.

Можна зменшити просторову когерентність лазерного освітлення, тобто декорелювати лазерні пучки, що падають на екран під різними кутами. Два декорельовані лазерні пучки будуть давати два декорельовані спеклові поля, коли їхній кут падіння відрізняється більше ніж на кутову апертуру зіниці ока людини, яка спостерігає зображення. Оскільки кут падіння можна змінювати в двох ортогональних напрямках, то цей метод дозволяє отримати декілька тисяч декорельованих спеклових полів. Однак для цього необхідно знайти метод декореляції лазерних пучків, що падають під різними кутами. Існують активні та пасивні способи зменшення просторово-часової когерентності лазерного пучка світла:

1) активні - методи, які пов'язані з механічним рухом;

2) пасивні - методи, які не вимагають механічного руху.

\section{1. Активні методи зменшення спеклових шумів}

В активних методах декореляція лазерних пучків, що падають під різними кутами, досягається за рахунок механічного руху, і тому ніяких умов на когерентність лазерного освітлення не накладається.

Одним із ефективних методів зменшення спеклового шуму $є$ розміщення рухомого стохастичного дифузора в оптичній системі проектора в площині, що спряжена до площини екрана $[10,11]$. Цей метод дозволяє знизити спекли значно нижче чутливості ока людини [11]. Проте використання дифузора має певні технологічні недоліки, такі як необхідність дуже швидкого зміщення дифузора за відсутності простого механізму його зміщення, значні втрати енергії унаслідок розсіювання поза об'єктив, відсутності простої і дешевої технології виготовлення дифузора з параметрами, що необхідні для даної оптичної системи. Тому рядом авторів було запропоновано використовувати регулярні дифракційні елементи за- 
мість стохастичного дифузора [12-14]. У [15] розроблено загальну теорію зменшення спеклів такими структурами.

У роботі [12] як регулярний бінарний дифузор пропонується 2D-дифракційний оптичний елемент (ДОЕ), що складається 3 квадратних матриць, структура яких базується на основі матриці Адамара (рис. 5). На кожен піксель зображення розміщується не менше однієї елементарної структури ДОЕ.

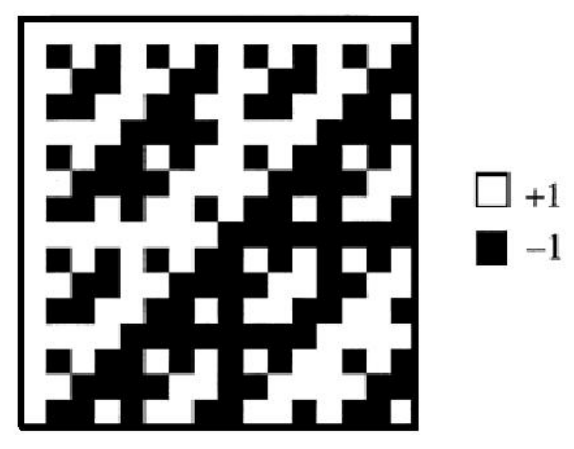

Рис. 5. Матриця Сильвестра $H(16)$ [12]

Оптимальне зменшення спеклів такої структури вимагає знаходження кожної структури над кожним пікселем за час інтегрування сигналу оптичним приладом (оком). Проте застосування такого ДОЕ $є$ проблематичним, оскільки потрібно мати метод заміщення одної матриці на інші, використовуючи механічні зміщення, що є надзвичайно складною задачею. Звичайно, заміну матриць можна здійснити електричним шляхом, якщо виконати ДОЕ з рідкокристалічних матриць [1517]. Проте швидкість перемикання рідкокристалічних оптичних матричних модуляторів є набагато нижчою за необхідну для ефективного зменшення спеклів у лазерних проекторах.

Задача механічного зміщення регулярних ДОЕ значно спрощується при застосуванні двовимірних (2D) ДОЕ структур, що засновані на псевдовипадкових бінарних послідовностях з використанням коду Баркера. В роботах $[18,19]$ було показано як створити на основі одновимірних послідовностей двовимірні ДОЕ і було доказано їхню високу ефективність зі зменшення спеклів. Було показано, що для зменшення спеклових шумів ДОЕ, що встановлений у середину оптичної схеми проектора у спряженій до площини екрана, повинен просто поступально рухатися. При цьому кут $\alpha$ нахилу ребер ДОЕ щодо напрямку його переміщення (рис. 6) повинен задовольняти умові [20]

$$
\operatorname{tg}(\alpha)=1 / m N,
$$

а зміщення ДОЕ $S$ за час інтегрування світлової інтенсивності оком (за інтервал часу, рівний часовій роздільній здатності ока) повинно становити

$$
S=N m T,
$$

де $N$ - довжина коду псевдовипадкової послідовності; $T$ - лінійний період ДОЕ; $m$ - будь-яке ціле число. 3 формули (4) випливає, що мінімальне лінійне зміщення на довжину $N$ періодів коду псевдовипадкової послідовності є необхідним для 
досягнення оптимального зменшення спеклових шумів. Було показано [14], що при значеннях $m>3$ практично досягається декореляція усіх дифракційних порядків, і максимальне значення коефіцієнта зменшення спеклів $k=1,4 N$. Було теоретично доказано [14] і експериментально підтверджено [21], що реалізація цього методу за допомогою двох одновимірних структур, які розташовані на різних поверхнях, дає можливість ефективного зменшення спеклів у всьому видимому діапазоні світлового спектра.

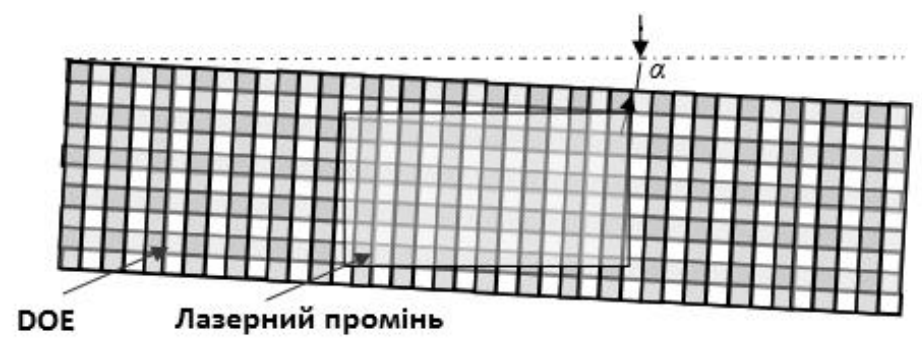

Рис. 6. Схема методу спекл-подавлення з горизонтальним зміщенням прозорої пластини зі структурою DOE [18]

Існує оптична схема, в якій пристрій зменшення спеклів і пристрій вирівнювання інтенсивності поєднані $[22,23]$. Ця схема показана на рис. 7 , де використано два дифузори. Вібрація першого дифузора здійснюється за допомогою вібратоpa VCM (Voice Coil Motors). В експерименті використовувалися дифузори з різними ефективними кутами розсіювання: $5^{\circ} \times 5^{\circ}, 10^{\circ} \times 10^{\circ}$ та $30^{\circ} \times 30^{\circ}$ [22].

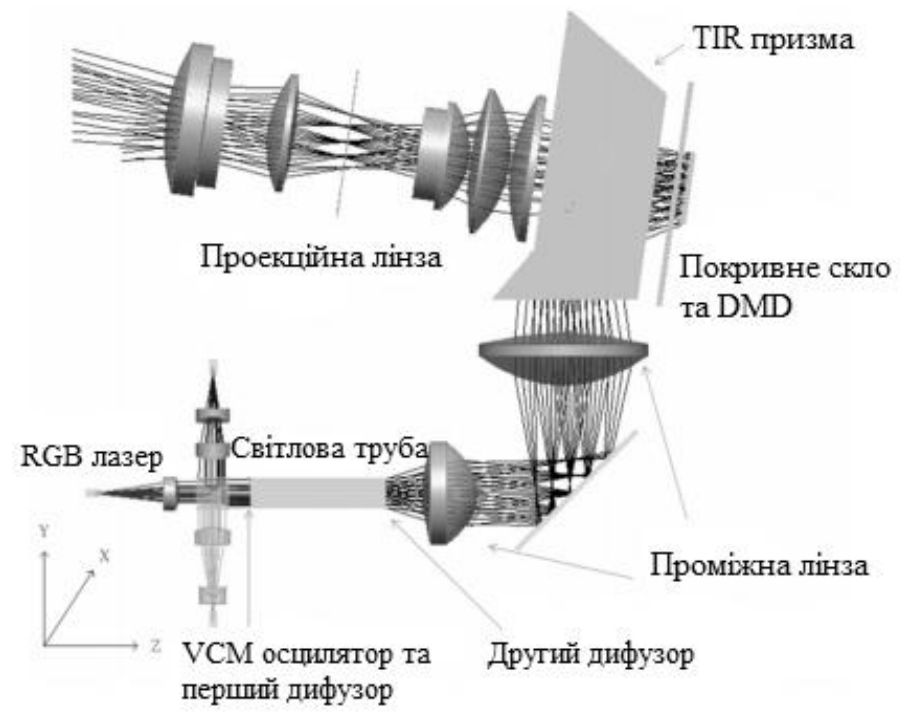

Рис. 7. Макет лазерного проектора з використанням вібруючого дифузора [23]

При застосуванні максимально високої амплітуди вібрації цим методом вдалося зменшити амплітуду спеклових шумів у 3 рази. Відносно малий рівень спеклів, отриманих в експерименті $\left(\sim 5^{\circ}\right)$, пояснюється некоректною методикою вимі- 
рювання спеклових шумів, а саме: великою апертурою камери, яка була використана в експерименті, внаслідок чого на один фотодіод потрапило більше десяти спеклів, і спекл-контраст зменшився внаслідок усереднення на одному фотодіоді.

У [24] запропоновано складнішу оптичну схему, в якій використовується два дифузори та деформуюче дзеркало. У цьому методі досягнуто значно більшого зменшення спеклів, а саме: зменшено інтенсивність спеклів у 10 разів. Проте, внаслідок того, що дзеркало забезпечує слабку розбіжність лазерного пучка $<3^{\circ}$, ефект зменшення спеклів тут досягається при збільшені оптичної системи.

Можна отримати ефект зменшення спеклів (з використанням кутового різноманіття) шляхом вібрації або обертання світлової труби [25], або багатомодових волокон [26]. Проте, цей метод вимагає вібрації великого діаметра (кілька сантиметрів) і довгої (принаймні в декілька діаметрів) світлової труби.

\section{2. Пасивні методи зменшення спекиів}

При пасивних методах використовується кінцева ширина спектра лазерного пучка для декореляції пучків світла, що розповсюджуються під різними кутами. Для цього лазерні пучки, що падають під різними напрямками на екран, вимушені проходити різну відстань. Просторова когерентність лазерного світла може бути зменшена без механічного зміщення або електричного перемикання. Для цього використовують неодномодові лазерні діоди і конвертують часову в просторову некогерентність, розбиваючи колімований лазерний пучок на лазерні пучки, що розповсюджуються під різними кутами з наступною зміною оптичного шляху для декореляції між пучками. Найпростіше цей метод реалізований у [27], де лазерний пучок розбивається за допомогою дифракційної гратки. Різниця оптичного шляху отримується шляхом розміщення діелектричних пластин різної товщини у фокальній площині (Фур'є-площині) проектора. Проте, внаслідок малої глибини Фур'є-площини, у цьому методі можна отримати декореляції всього декількох лазерних пучків і досягти в найкращому випадку дворазового зменшення інтенсивності спеклових шумів. Більший ефект можна досягти з використанням багатомодового волокна. Для цього на вході оптоволокна розміщують дифузор. При падінні на нього колімований лазерний пучок розпушується і розпадається за модами оптоволокна. Кожна мода оптоволокна має різну дисперсію, тобто різну швидкість розповсюдження. Внаслідок цього, при достатній довжині оптоволокна, поля різних мод можна декорелювати. Разом з тим, різні моди випромінюються під різними кутами, і таким чином часова некогерентність переходить у просторову. В [28] теоретично показано, що для реальних лазерних діодів і пучка багатомодових оптичних волокон довжиною близько 2 метрів можна отримати лазерний проектор з контрастом спеклів менше 1 \%. Проте, внаслідок необхідності застосовувати пучок довгого оптоволокна, цей метод важко застосувати для мобільних лазерних проекторів. Отже ефективність пасивних методів зменшення спеклових шумів залежить від ширини спектра, а також ці методи вимагають збільшення розмірів системи для отримання достатньої різниці оптичного шляху для декореляції лазерних пучків. Тому пасивні методи боротьби зі спеклами не можуть зменшити спекли нижче порогу чутливості ока людини в переносних лазерних проекTopax. 


\section{Висновки}

Для зменшення спеклових щумів розроблено та запропоновано чимало методів зменшення спеклів з різною практичністю та ефективністю. Зазвичай ці методи включають у себе усереднення розмірів і варіацію положення спекла, формування оптичної різниці фаз спеклів, що виникають в одному і тому ж місці, але в різні моменти часу.

Ефективність і практичність різних методів можуть бути залежними від архітектури проекційної системи. Аналіз технологій зменшення спеклових шумів показав, що більшість запропонованих методів $є$ малоефективними (розсіюють світло), мають складний рівень технології або значно впливають на розмір пристроїв. Тому оптимально проблема зменшення спеклових шумів у переносних лазерних проекторах повинна бути вирішена економічно ефективним способом без утрати переваг, що пов'язані з використанням лазерних джерел.

1. Dudley D., Duncan W.M. and Slaughter J. Emerging digital micromirror device (DMD) applications. Proc. SPIE. 2003. Vol. 4985. P. 14-25.

2. Bloom D.M. Grating Light Valve: Revolutionizing Display Technology. Proc. SPIE. 1997. Vol. 3013. P. $165-171$.

3. SangKyeong Yun, JongHyeong Song, InJae Yeo, YoonJoon Choi, Yurlov Victor [et all.]. Spatial optical modulator (SOM): high-density diffractive laser projection display. Proc. Of SPIE. 2007. Vol. 6487. P. 648710-1-648710-10.

4. Yun S.K., Song J., Lee T.-W., Yeo I., Choi Y. [et all.]. Spatial Optical Modulator (SOM): Samsung's Light Modulator for the Next Generation Laser Display. IMID/IDMC '06 DIGEST (Proc. Of Society for Information Display - SID. August, 2006. 29-1. P. 551-555.

5. Kowarz M.W., Brazas J.C. and Phalen J.G. Conformal Grating Electromechanical system (GEMS) for High-Speed Digital Light Modulation. IEEE, 15th Int. MEMS, Digest., January 20-24, 2002. Las Vegas, NV, USA: IEEE, 2002. P. 47.

6. Urey H., Wine D., Osborn T. Optical performance requirements for MEMS-scanner based microdisplays. Proc. SPIE. Santa Clara, CA. Sep 2000. Vol. 4178. P. 176-185.

7. Brennesholtz M.S. and Stupp E.H. Projection Displays. Wiley, 2008.

8. Verschaffelt G., Roelandt S., Meuret Y., Van den Broeck W., Kilpi K., Lievens B., Jacobs A., Janssens P. and Thienpont H. Speckle disturbance limit in laser based cinema projection systems. Sci. Rep. 2015. 5. 14105.

9. Speckle suppression in laser projection displays. Trinh Thi Kim Tran. Doctoral Thesis. 2015.

10. Wang L., Tschudi T., Halldórsson T. and Pétursson P.R. Speckle reduction in laser projection systems bydiffractive optical elements. Appl. Opt. 1998. 37(10). P. 1770-1775.

11. Kubota S. and Goodman J.W. Very efficient speckle contrast reduction realized by moving diffuser device. Appl. Opt. 2010. 49. P. 4385-4391.

12. Trisnadi J.I. Hadamard speckle contrast reduction. Opt. Lett. 2004. 29. P. 11-13.

13. Yurlov Victor, Lapchuk Anatoly, Yun Sangkyeong, Song Jonghyeong and Yang Haengseok. Speckle suppression in scanning laser display. Appl. Opt. 2008. Vol. 47. N 2. P. 179-187.

14. Akram M.N., Kartashov K. and Tong Z. Speckle reduction in linescan laser projectors using binary phase codes. Opt. Lett. 2010. 35. P. 444-446.

15. Lapchuk A., Prygun O., Fu M., Le Z., Xiong Q. and Kryuchyn A. Dispersion of speckle suppression efficiency for binary DOE structures: spectral domain and coherent matrix approaches. Opt. Expr. 2017. Vol. 25. N 13. P. 14575-14597.

16. Gao Wenhong, Tong Zhaomin, Kartashov Vladimir, Akram Muhammad Nadeem and Chen Xuyuan. Replacing Two-Dimensional Binary Phase Matrix by a Pair of One-Dimensional Dynamic Phase Matrices for Laser Speckle Reduction. J. Display Technol. 2012. 8. P. 291-295.

17. Thomas W., Middlebrook Ch. Non-moving Hadamard matrix diffusers for speckle reduction in laser pico-projectors. J. Mod Opt. 2014 December 12; 61(sup1): S74-S80. 2014. 
18. Lapchuk A., Kryuchyn A., Petrov V., Shyhovets O., Pashkevich G., Bogdan O., Kononov A. and Klymenko A. Optical schemes for speckle suppression by Barker code diffractive optical elements. J. Opt. Soc. Am. 2013. A 30(9). P. 1760-1767.

19. Lapchuk A., Kryuchyn A., Petrov V., Yurlov V. and Klymenko V. Full speckle suppression in laser projectors using two Barker code-type optical diffractive elements. J. Opt. Soc. Am. 2013. A 30. P. 22-31.

20. Lapchuk A., Kryuchyn A., Petrov V., Yurlov V. and Klymenko V. Optimal speckle suppression in laser projectors using a single two-dimensional Barker code diffractive optical element. $J$. Opt. Soc. Am. 2013. A 30. N 2. P. 227-232.

21. Lapchuk A., Yurlov V., Krychyn A., Pashkevich G., Klymenko V. and Bogdan D. Impact of speed, direction, and accuracy of diffractive optical element shift on efficiency of speckle suppression. Appl. Opt. 2015. Vol 54. N 13. P. 4070-4075.

22. Lapchuk A., Pashkevich G., Prygun O., Kosyak I., Fu M., Le Z. and Kryuchyn A. Very efficient speckle suppression in the entire visible range by one two-sided diffractive optical element. Appl. Opt. 2017. 56(5). P. 1481-1488.

23. Pan J.-W. and Shih Ch.-H. Speckle reduction and maintaining contrast in a LASER picoprojector using a vibrating symmetric diffuser. Opt. Expr. 2014. Vol. 22. N 6. P. 6464-6477.

24. Chen H-A., Pan J.I-W. and Yang Z.-P. Speckle reduction using deformable mirrors with diffusers in a laser pico-projector. Opt. Expr. 2017. Vol. 25. N 15. P. 18140-18151.

25. Trisnadi J.I., Carlisle C.B. and Monteverde V. Overview and applications of grating light valve TM based optical write engines for high-speed digital imaging. Proc. SPIE. 2004. Vol. 5348. P. 52-64.

26. Petoukhova A.L., Cleven E., M de Mul F.F. Steenbergen W. Suppression of Dynamic Laser Speckle Signals in Multimode Fibers of Various Lengths. Applied Optics. 2004. 43(10):2059-65.

27. An S., Lapchuk A., Yurlov V., Song J., Park H.W., Jang J., Shin W., Kargapoltsev S. and Yun S.K. Speckle suppression in laser display using several partially coherent beams. Optics Express. 2017. Vol. 17. N 1. P. 92-103.

27. Manni J.G. and Goodman J.W. Versatile method for achieving $1 \%$ speckle contrast in largevenue laser projection displays using a stationary multimode optical fiber. Optics Express. 2012. Vol. 20. N 10. P. 11288-11312.

Надійшла до редакції 18.05.2018 